\title{
Pathomorphological features and mast cell count in canine visceral hemangiosarcomas
}

\author{
Andrea Gudan Kurilj ${ }^{1}$, Krešimir Severin², Marko Hohšteter ${ }^{1 *}$, Branka Artuković ${ }^{1}$,

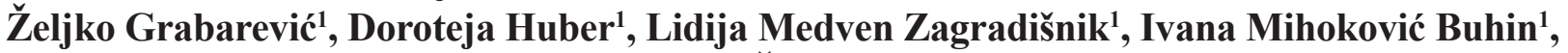 \\ and Ivan-Conrado Šoštarić-Zuckermann ${ }^{1}$ \\ ${ }^{1}$ Department of Veterinary Pathology, Faculty of Veterinary Medicine, University of Zagreb, Zagreb, Croatia \\ ${ }^{2}$ Department of Forensic and Juridical Veterinary Medicine, Faculty of Veterinary Medicine, University of Zagreb, \\ Zagreb, Croatia
}

GUDAN KURILJ, A., K. SEVERIN, M. HOHŠTETER, B. ARTUKOVIĆ, Ž. GRABAREVIĆ, D. HUBER, L. MEDVEN ZAGRADIŠNIK, I. MIHOKOVIĆ BUHIN, I.-C. ŠOŠTARIĆ-ZUCKERMANN: Pathomorphological features and mast cell count in canine visceral hemangiosarcomas. Vet. arhiv 91, 159-168, 2021.

\section{ABSTRACT}

Visceral hemangiosarcoma were analyzed at the Department of Veterinary Pathology of the Faculty of Veterinary Medicine, University of Zagreb, over a 5-year period. From a total of 52 tumor masses in a total of 31 dogs, histological growth patterns (cavernous, capillary or solid) and the amount of tumor supporting stroma were evaluated. Additionally, sections were stained with toluidine blue for the purpose of mast cell detection and their number was determined in the tumor parenchyma, tumor stroma and edges. The average age of the affected animals was 10 years, males predominated, and the tumors occurred most frequently in cross breeds, German Shepherd dogs and Labrador Retrievers. The highest number of visceral hemangiosarcoma was found in the spleen (27/52). The most common growth pattern of visceral hemangiosarcoma was solely cavernous with a mixture of cavernous and solid patterns in different proportions. Mast cells were found in 44/52 (84.6\%) of the visceral hemangiosarcomas. A smaller number of mast cells were found in the tumor parenchyma, and higher number were found in the stroma and tumor edges. The number of mast cells in tumors was not significantly associated with the tumor growth pattern, but there was a positive correlation between MCC - tumor parenchyma and stroma $\left(r_{s}=0.28, P<0.05\right), M C C$ - tumor stroma + edges $\left(r_{s}=0.74\right.$, $\mathrm{P}<0.05)$ and MCC - tumor parenchyma and MCC- tumor stroma+edges $\left(\mathrm{r}_{\mathrm{s}}=0.30, \mathrm{P}<0.05\right)$ in all the examined tumors. In splenic tumors, there was only a significant positive correlation between $\mathrm{MCC}-\operatorname{stroma}+\mathrm{edges}\left(\mathrm{r}_{\mathrm{s}} \mathrm{P}=0.68 \mathrm{P}<0.05\right)$. These results suggest a higher mast cell count in tumors with more developed stromal components in canine visceral hemangiosarcomas, and certainly indicate the need for further research on their role and the factors they release in the development and progression of hemangiosarcomas.

Key words: dog; visceral hemangisarcoma; mast cell; stroma

\footnotetext{
*Corresponding author:

Marko Hohšteter, DVM, PhD, Department of Veterinary Pathology, Faculty of Veterinary Medicine, University of Zagreb, Heinzelova 55, 10000 Zagreb, Croatia, Phone: +385 1 2390314, E-mail: hohi@vef.hr
} 


\section{Introduction}

Hemangiosarcomas (HSA) are malignant neoplasms characterized by aggressive growth, early metastasis, and an unfavorable prognosis. Hemangiosarcomas can develop in any vascularized tissue, however the most common primary site of visceral hemangiosarcomas in dogs is the spleen (LINDER, 2017). Hemangiosarcomas most commonly affect dogs aged 6 to 17 years, and affect a variety of breeds including cross breeds. Several studies have shown that Golden Retrievers, Labrador Retrievers and German Shepherds are at greatest risk for developing HSA (SCHULTHEISS, 2004; BOSTON et al., 2011; LINDER, 2017).

Histologically, hemangiosarcomas are characterized by the proliferation of neoplastic endothelial cells that create vascular spaces filled with blood. The vascular spaces can be of different sizes, and they are divided by thin collagen trabeculae. Sometimes more solid areas of neoplastic cells are visible in HSA. So the growth patterns vary, and capillary, cavernous and solid areas may be found (GÖRITZ et al., 2013). Such growth patterns are only descriptive and are not used for prognostic purposes (LINDER, 2017). However, the study by GÖRITZ et al., 2013, suggested the shortest survival time was in dogs with cavernous HSA, which is possibly related to the fact that these lesions frequently rupture, leading to extensive hemorrhage. Furthermore, recognition of certain HSA growth patterns is also of diagnostic relevance because well-differentiated capillary parts could be mistaken for irregular granulation tissue, solid areas for other splenic sarcomas, and cavernous parts could be mistaken for hemangioma (GÖRITZ et al., 2013). Since there are often several histological types in a single tumor and HSA is often accompanied by bleeding and hematomas, it is very important to examine a sufficient number of samples during the histological examination to avoid misdiagnosis. The survey by HERMAN et al., 2019, emphasized the need to submit the entire spleen for histopathological examination in suspected cases of hemangiosarcoma, and suggested that 5 sections obtained by a trained individual are likely sufficient for diagnosis. Additionally, in poorly differentiated tumors, immunohistochemistry using antibodies specific for endothelial cells (von Willebrand factor, CD31, vascular endothelial growth factor and its receptor) should be used to confirm the diagnosis of HSA (SABATINI and BETTINI, 2009; GÖRITZ et al., 2013).

Mast cells (MCs) originate and differentiate from a $\mathrm{CD} 34+$ precursor cell in the bone marrow. They play the most important role in immunoglobulin E (IgE) mediated hypersensitivity reactions (ACKERMANN, 2017). In addition to inflammatory reactions, mast cells are known to play an important role in the progression and angiogenesis of some human tumors. They have been shown to promote angiogenesis in basal cell carcinomas (AOKI et al., 2003), plasmacytomas (NAKAYAMA et al., 2004), squamous cell carcinomas, and lung adenocarcinomas (TOMITA et al., 2000). Several mast cell mediators probably have angiogenic activity and, among other functions, may regulate proliferation of endothelial cells, and degrade the extracellular matrix. MCs may play pro-angiogenic but also anti-angiogenic roles in infantile hemangioma (YAMAMOTO et al., 2000; SUN et al., 2007). There are few studies about the presence and possible role of mast cells in animal tumors. MUKARATIRWA et al. (2006a and b) investigated the association between areas of high vascular density and mast cell counts in dogs with melanoma and transmissible venereal tumors. SCHULTHEISS (2004) found an increased number of mast cells in visceral and nonvisceral hemangiomas and hemangiosarcomas in domestic animals, but no association was found between the degree of tumor differentiation and the number of mitoses, and the number of mast cells. SABATTINI and BETTINI (2009) identified a higher number of mast cells in cutaneous and visceral hemangiomas than in hemangiosarcomas, and hypothesized their possible role in the pathogenesis of benign vascular neoplasia. WOLDEMESKEL and RAJEEV (2010) found that a higher mast cell count in canine mammary tumors was also associated with angiogenesis, but they did not find a significant difference in mast cell count between cutaneous 
HSA and hemangiomas. An association between angiogenesis and mast cell count has also been found in canine lymphomas (WOLDEMESKEL et al., 2014).

From previous research it is evident that mast cells are present in canine hemangiomas and hemangiosarcomas, but compared to cutaneous hemangiomas and hemangiosarcomas, there is a relatively small number of studies on mast cell count (MCC) and certain pathological features of visceral hemangiosarcoma in different organs. The present study was conducted to (1) gather information about the number of dogs affected by visceral HSA over a five-year period in Croatia, (2) to clarify histological growth patterns and the amount of tumor supporting stroma, and (3) to determine the number of mast cells and their correlation with histological characteristics in canine visceral HSA.

\section{Materials and methods}

All cases of hemangiosarcoma submitted to the Department of Veterinary Pathology, Faculty of Veterinary Medicine, University of Zagreb, during the period from 2014 to 2018 were identified. The age, breed and sex of the affected animals and organs were reviewed. All samples were formalin fixed, processed for routine histology, paraffin embedded and stained routinely with hematoxylin and eosin (HE). Each tumor was assigned to a specific histological growth pattern according to GÖRITZ et al., 2013. Additionally, a semiquantitative assessment of fibrous tumor stroma was performed, as follows: very scant fibrous tissue (0), mild (1), moderate (2) or severe (3) tumor stroma. The degree of severity was defined as follows (percentage of total tumor stroma per tissue section): very scant fibrous tissue $(0)$, mild $(<10 \%)$, moderate $(10-40 \%)$ or severe $(>40 \%)$.

For mast cell visualization, $4 \mu \mathrm{m}$ thin sections were de-waxed, rehydrated and stained in Toluidine blue solution (Toluidine blue, Merck KGaA). The number of mast cells in the tumor parenchyma and within the tumor stroma and edges were counted in 10 randomly selected fields $(\mathrm{x} 400)$ inside a square reticulum (Olympus, $20.4 \mathrm{~mm}^{2}$ ) inserted into the ocular piece of a light microscope, as described in Table 1.
Table 1. Determination of mast cell count in canine visceral HSA.

\begin{tabular}{|l|c|}
\hline Mast cell count & Score \\
\hline No mast cells & 0 \\
\hline Rare mast cells (1 to 9) & 1 \\
\hline Medium number of mast cells (10 to 24$)$ & 2 \\
\hline Large number of mast cells (25 to 50$)$ & 3 \\
\hline
\end{tabular}

Statistics. One-way ANOVA with post hoc Tukey's test and Spearman's rank correlation coefficient were used for statistical analysis to test for an association between: the HSA growth pattern and mast cell count in the tumor parenchyma and in the tumor stroma and edges; MCC in the tumor parenchyma and in the tumor stroma and edges and tumor stroma development. Results were considered statistically significant if $\mathrm{P}<0.05$. Statistical analyses were performed using STATISTICA (data analysis software system, version 10.0; StatSoft, Inc., Tulsa, Oklahoma, USA). Analysis was performed for all samples as a group and separately for the spleen, while other organs were not tested separately, due to the small number of samples.

\section{Results}

During the period from 2014 to 2018, 31 cases of canine visceral hemangisarcoma were submitted to the Department of Veterinary Pathology, Faculty of Veterinary Medicine, University of Zagreb. Out of $19 \operatorname{dogs}(61.3 \%)$, surgical biopsy of the affected organ or spleen with hemangiosarcoma were submitted for histopathological examination, and 12 dogs with hemangiosarcoma (38.7\%) were submitted for necropsy. The mean age of dogs with HSA was 10 years (range 7 - 15 years). Predominantly dogs of mixed breed were affected ( $\mathrm{n}=12,38.7 \%$ ), followed by German Shepherds $(\mathrm{n}=5,16.1 \%)$ and Labrador Retrievers $(\mathrm{n}=3$, 9.7\%). Two cases of HSA were found in American Staffordshire Terriers, Golden Retrievers and Beagles, and one case in a Gordon Setter, Maltese, Rhodesian Hound and Akita Inu. For one dog the breed was unknown. Males accounted for $71 \%$ $(22 / 31)$ of cases and females $29 \%(9 / 31)$.

Regarding the affected organs, a total of 52 tumor masses were identified in a total of $31 \mathrm{dogs}$. 
The organ most affected with hemangiosarcoma was the spleen $(\mathrm{n}=27,51.9 \%)$, followed by the liver $(\mathrm{n}=10,19.2 \%)$ and the right atrium $(\mathrm{n}=5,10$ $\%)$. The lung and omentum were affected in 4 cases each $(7.7 \%$ each), and the bladder and kidney in one case each (2\%).

Regarding all the examined tumors, in 28 tumors (54\%) one growth pattern was found, and mixed tumors with the appearance of two or all three growth patterns were found in 24 tumors (46\%). The most common growth pattern of visceral HSA was a solely cavernous pattern, with a mixture of cavernous and solid patterns in different proportions. The most common growth pattern of HSA in the spleen was a mixture of solid and cavernous patterns in different proportions within a single tumor $(n=13,25 \%)$. Five splenic HSAs showed a solely cavernous and four splenic HSAs a solely solid growth pattern (Fig. 1a, b, c). A solid component of the HSAs was also common in combination with a cavernous or capillary growth pattern in tumors arising from the right atrium. Metastatic tumors in the liver, lungs, omentum and kidneys were mostly characterized by cavernous and capillary growth patterns. The amount of fibrous tissue (tumor stroma) was most pronounced in the omentum and the right atrium, it was moderate in the liver and spleen, and weakest in the lung (Fig. 2). In a large number of tumors, especially in the omentum and liver, the stroma continued to the connective tissue at the periphery of the tumor, and therefore in the determination of mast cell count, the tumor stroma and edges were considered as one entity.
Organs affected by HSAs in dogs submitted for necropsy and the individually affected organs of dogs (which were alive at the time of surgery and diagnosis of HSA), and the histological growth pattern of the HSAs are shown in Tables 2 and 3.

Out of a total of 52 tumor samples, mast cells were found in 44 tumors $(84.6 \%)$. In all affected organs, the number of mast cells was the lowest in the tumor parenchyma (between tumor cells), and a higher number of mast cells was observed within the tumor stroma and on the periphery of the tumors (Fig. 3 a-d). Regarding the type of affected organs, a larger number of mast cells in the tumor parenchyma, within the tumor stroma and on edges of the tumor was observed in the liver, omentum and right atrium. A lower number of mast cells was observed in the spleen. The ratios of the mast cell count in the parenchyma of the HSAs, in stroma/ edges and the amount of tumor stroma in the affected organs are shown in Fig. 4.

There were no statistically significant differences between the HSA growth pattern and MCC in the tumor parenchyma, or in the tumor stroma and edges. However, among all the examined visceral tumors we found a significant positive correlation between MCC - tumor parenchyma and stroma $\left(\mathrm{r}_{\mathrm{s}}\right.$ $=0.28, \mathrm{P}<0.05), \mathrm{MCC}-$ tumor stroma + edges $\left(\mathrm{r}_{\mathrm{s}}=\right.$ $0.74, \mathrm{P}<0.05)$ and $\mathrm{MCC}$ - tumor parenchyma and $\mathrm{MCC}$ - tumor stroma+edges $\left(\mathrm{r}_{\mathrm{s}}=0.30, \mathrm{P}<0.05\right)$. In splenic tumors, we only found a significant positive correlation between MCC - stroma+edges $\left(\mathrm{r}_{\mathrm{s}} \mathrm{P}=\right.$ $0.68 \mathrm{P}<0.05$ ).

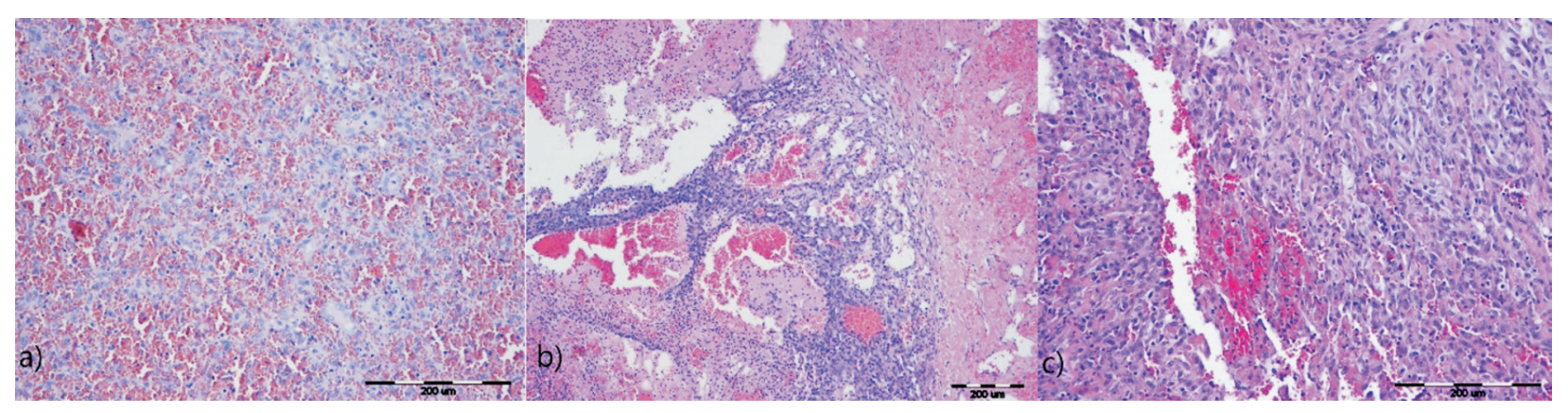

Fig. 1. Splenic HSA, a) capillary $(H \& E, \times 20)$, b) cavernous $(H \& E, \times 10)$ and c) solid $(H \& E, \times 20)$ growth patterns. 
A. Gudan Kurilj et al.: Mast cells in canine visceral hemangiosarcoma

Table 2. Organs affected by HSA and histological growth patterns of tumors in dogs submitted for necropsy

\begin{tabular}{|c|c|c|}
\hline Breed & Organ & Growth pattern \\
\hline \multirow{3}{*}{ German Shepherd } & spleen & all growth patterns \\
\hline & liver & capillary \\
\hline & lung & cavernous \\
\hline \multirow{2}{*}{ American Staffordshire Terrier } & spleen & solid \\
\hline & omentum & cavernous \\
\hline \multirow{3}{*}{ German Shepherd } & urinary bladder & cavernous $>$ solid \\
\hline & liver & cavernous $>$ solid \\
\hline & spleen & cavernous $>$ solid \\
\hline \multirow{2}{*}{ Gordon Setter } & spleen & all growth patterns \\
\hline & liver & capillary \\
\hline \multirow{3}{*}{ German Shepherd } & lung & solid $>$ capillary \\
\hline & right atrium & solid \\
\hline & spleen & cavernous $>$ solid \\
\hline \multirow{4}{*}{ Labrador Retriever } & right atrium & solid $>$ cavernous \\
\hline & liver & cavernous \\
\hline & kidney & cavernous \\
\hline & spleen & solid $>$ cavernous \\
\hline \multirow{3}{*}{ Mixed Breed } & right atrium & all growth patterns \\
\hline & spleen & cavernous \\
\hline & omentum & cavernous \\
\hline \multirow{5}{*}{ Golden Retriever } & liver & cavernous $>$ capillary \\
\hline & right atrium & capillary $>$ solid \\
\hline & lung & capillary \\
\hline & omentum & capillary \\
\hline & spleen & cavernous \\
\hline \multirow{3}{*}{ Mixed Breed } & right atrium & cavernous $>$ solid \\
\hline & liver & cavernous \\
\hline & lung & cavernous \\
\hline \multirow{2}{*}{ Beagle } & spleen & cavernous $>$ solid \\
\hline & liver & solid \\
\hline German Shepherd & spleen & solid $>$ cavernous \\
\hline \multirow{2}{*}{ Mixed Breed } & liver & capillary \\
\hline & spleen & cavernous $>$ solid \\
\hline
\end{tabular}


Table 3. Single organs affected by HSA and histological growth patterns of tumors in dogs that were alive at the time of surgery and tumor diagnosis

\begin{tabular}{|c|c|c|}
\hline Breed & Organ & Growth pattern \\
\hline Mixed Breed & spleen & cavernous \\
\hline Mixed Breed & spleen & solid $>$ cavernous \\
\hline Mixed Breed & spleen & solid $>$ cavernous \\
\hline Mixed Breed & spleen & solid $>$ cavernous \\
\hline Maltese & spleen & solid $>$ cavernous \\
\hline Unknown & spleen & solid \\
\hline Beagle & spleen & solid \\
\hline Rhodesian Ridgeback & spleen & capillary \\
\hline Labrador Retriever & spleen & solid $>$ cavernous \\
\hline Labrador Retriever & spleen & capillary \\
\hline Akita Inu & spleen & cavernous \\
\hline Mixed Breed & spleen & solid $>$ cavernous \\
\hline Mixed Breed & spleen & cavernous \\
\hline Golden Retriever & spleen & solid \\
\hline German Shepherd & spleen & solid $>$ cavernous \\
\hline Mixed Breed & spleen & capillary \\
\hline American Staffordshire Terrier & liver & solid \\
\hline Mixed Breed & omentum & solid $>$ cavernous \\
\hline Mixed Breed & liver & cavernous \\
\hline
\end{tabular}

Tumor stroma

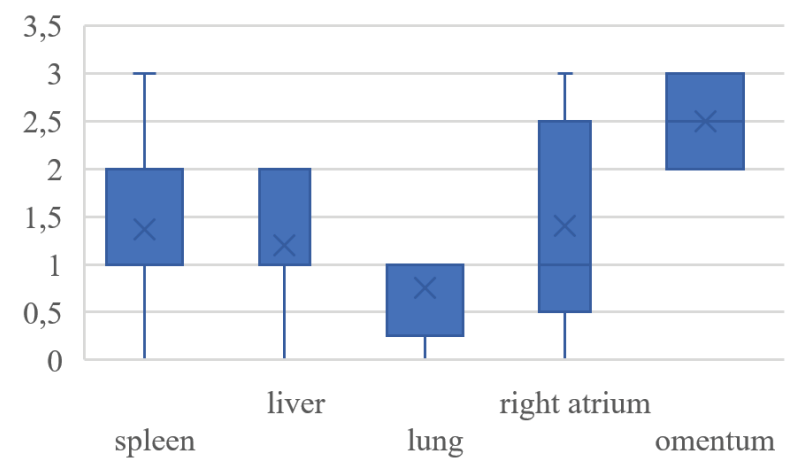

Fig. 2. The amount of tumor stroma in organs affected by HSA 


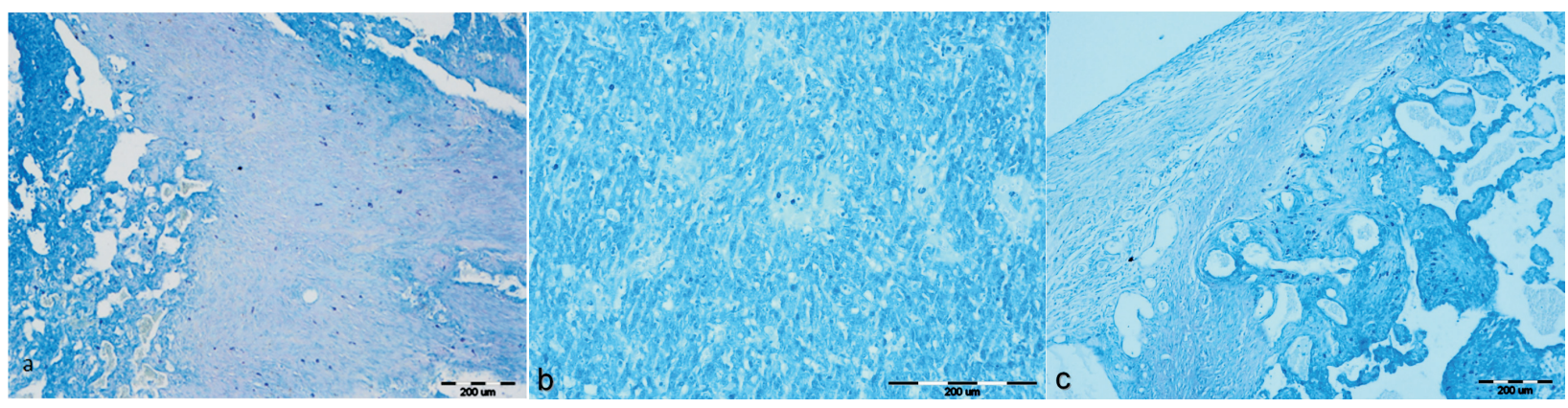

Fig. 3. a) Spleen, a large number of mast cells within the tumor stroma (Toluidine blue, $\times 10$ ); b) Spleen, a few mast cells within the tumor parenchyma (Toluidine blue, $\times 20$ ); c) Omentum; accumulation of mast cells on the tumor edge near the connective tissue on the periphery of the tumor (Toluidine blue, $\times 10$ ); d) Right atrium, a large number of mast cells between neoplastic cells (Toluidine blue, $\times 20$ ).

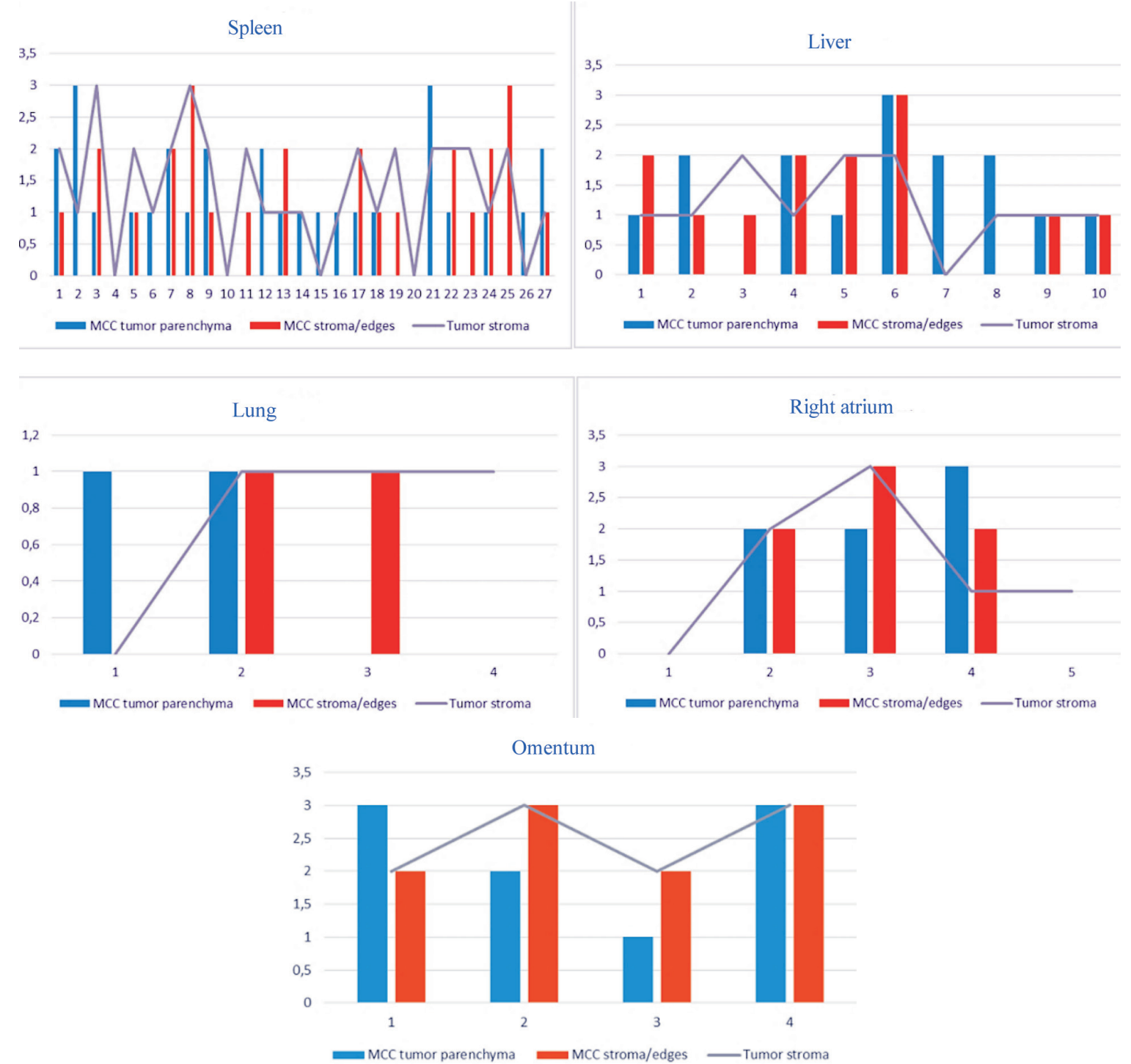

Fig. 4. The ratio of the mast cell count in the parenchyma of HSAs, in stroma/edges and the amount of tumor stroma in affected organs 


\section{Discussion}

The results of previous findings related to the distribution of age and sex of dogs with hemangiosarcomas (SABATTINI and BETTINI, 2009, GÖRITZ et al., 2013) were confirmed by the present study, where the average age of the affected dogs was 10 years, and male dogs were overrepresented. Although our study population of 31 dogs was small, the distribution of affected breeds was also similar to previous studies (SABATTINI and BETTINI, 2009; YAMAMOTO et al., 2013; GÖRITZ et al., 2013; TREGGIARI et al., 2020). The most common breed in which HSA was found was cross breeds, followed by German Shepherds and Labrador Retrievers. The slightly higher number of cross breed dogs in our study is probably a consequence of the higher representation of this breed in the dog population in Croatia.

The organ most commonly affected by HSA in our study was the spleen. Out of the 12 dogs submitted for necropsy, 11 had HSA in the spleen, with concurrent tumors or metastases in the liver (9), right atrium (5), lungs (4), omentum (3), and urinary bladder and kidney in one case each. In 19 cases of dogs that were alive at the time of surgery, the majority of the HSAs (16/19) were also in the spleen. These findings are consistent with previous research (BOSTON et al., 2011; GÖRITZ et al., 2013; LINDER, 2017) and indicate a large the likelihood that visceral HSAs are primarily splenic tumors. In dogs, hemangiosarcomas can occur concurrently in the spleen, subcutaneous tissue, and/or heart, usually involving the right atrium or auricle. However, even now it is not clear if this pattern represents metastases or the multicentric origin of HSAs (LINDER, 2017).

Histological growth patterns in HSAs are variable, and the concurrent presence of capillary, cavernous, and solid areas is common (LINDER, 2017). In the literature search we found a relatively small number of studies that include the significance of tumor growth patterns in HSAs. The research by GÖRITZ et al., 2013 was dominated by the high histological heterogeneity of these tumors, and the most common growth pattern was the occurrence of all three patterns within a single tumor. However, there was no significant difference in survival time for any particular growth pattern. SABATTINI and BETTINI, 2009, did not find any relationship between different morphological patterns and the anatomical location of hemangiosarcoma. In the present study, single growth patterns dominated slightly $(56.3 \%)$ with the cavernous growth pattern as the most common, while mixed types were found in $43.7 \%$ of tumors. Although the growth pattern of HSAs does not have a significant prognostic value, it is of diagnostic relevance, especially in cavernous tumor types that should not be confused with hemangioma or hematoma, and in capillary types that should not be mistaken for granulation tissue (GÖRITZ et al., 2013). One of the possible reasons why the single growth pattern of HSAs dominates slightly in our study is that very often only a part of the tumor or a part of the affected organ was submitted for histological examination, and thus fewer sections were made. Therefore, we point out the importance of the survey by HERMAN et al., 2019 that emphasized the need to submit the entire spleen for histopathological examination in suspected cases of hemangiosarcoma, and suggest that 5 sections yields a $95.02 \%$ chance of diagnosis of HSA, while examination of 10 sections yields a $98.59 \%$ chance of diagnosis when HSA is present.

In their study, which included 40 HSAs of which 29 were visceral, SABATTINI and BETTINI, 2009, found a small to moderate number of mast cells in 10 tumors, while in $72.5 \%$ of tumors they did not detect any MCs. In contrast, in our study MCs were found in a significantly larger number of tumors (44/52, 84.6\%). SABATTINI and BETTINI, 2009, did not specify the distribution of mast cells in HSA. In our study, a smaller number of mast cells was found in the parenchyma of the tumor, while a larger number was found in the stroma and on the periphery of tumors. These findings are similar to those of SCHULTHEISS, 2004, who also found mast cell infiltration in a small number of HSAs (16/76), but MC accumulation was greatest in the tumor stroma. Our findings are more similar to the distribution of $\mathrm{MCs}$ in the cutaneous hemangiomas and hemangiosarcoma identified by WOLDEMESKEL and RAJEEV, 2010. These authors found a higher number of MCs along the invasive edges in cutaneous HSAs and mammary 
gland adenocarcinomas than in cutaneous hemangiomas and mammary gland adenomas, and suggested that the number of MCs in tumors increases with malignancy. In addition, the higher number of mast cells in hemangiomas and HSAs than in mammary gland tumors suggests that mast cells are more numerous in vascular neoplasms (WOLDEMESKEL and RAJEEV, 2010).

In our study, there was no significant association between mast cell count and HSA growth pattern, either in the spleen or in all organs in total. The presence of mast cells in HSAs was also not associated with the degree of differentiation, mitotic index or other parameters evaluated (SCHULTHEISS, 2004). However, the present study showed that in organs with more developed stroma, a larger number of mast cells was present in the parenchyma, and especially in the stroma and at the tumor edges. This is probably because the microenvironment and stromal components vary in different tissues, and have an impact on the growth of neoplastic and non-neoplastic cells and on the infiltration of mast cells into such areas. Some authors suggest that in certain tumors the number of small blood vessels and the number of mast cells may be related to stromal components, and consequently tumors with more stroma may have more developed microcirculation and more mast cells (ELPEK et al., 2001). On the other hand, it is known that mast cells accumulate in the area of myocardial infarction during the proliferative phase of healing, and possibly regulate fibrous tissue deposition and angiogenesis by secreting growth factors, angiogenic factors and proteases (FRANGOGIANNIS and ENTMAN, 2006). Therefore, it is possible that in tumors, in addition to angiogenesis, mast cells with their products regulate the amount of connective tissue matrix (HIROMATSU and TODA, 2003). Finally, the presence of mast cells in visceral HSAs also has diagnostic significance. Namely, in the cytological examination of HSAs it is possible that the aspirates are composed of blood and mast cells. In such cases it is important not to misdiagnose mast cells as mast cell tumors (SCHULTHEISS, 2004).

In conclusion, the present study confirmed the presence of MCs in canine visceral HSAs and their association with the amount of connective tissue matrix in the HSA. This points to the need for further research on their role and factors they release in the development and progression of visceral hemangiosarcomas.

\section{References}

ACKERMANN, M. R. (2017): Inflammation and Healing. In: Pathologic Basis of Veterinary Disease. (Zachary J. F., Ed.). $6^{\text {th }}$ ed. Elsevier. pp. 83-84.

AOKI, M., R. PAWANKAR, Y. NIIMI, S. KAWANA (2003): Mast cell in basal cell carcinoma expresses VEGF, IL-8 and RANTES. Int. Arch. Allergy Immunol. 130, 216-223.

DOI: $10.1159 / 000069515$

BOSTON, S. E., G. HIGGINS, G. MONTEITH (2011): Concurrent splenic and right atrial mass at presentation in dogs with HSA: a retrospective study. J. Am. Anim. Hosp. Assoc. 47, 336-341.

DOI: $10.5326 / \mathrm{JAAHA}-\mathrm{MS}-5603$

ELPEK, G. Ö., T. GELEN, N. H. AKSOY, A. ERDOGAN, L. DERTSIZ, A. DEMIRCAN, N. KELES (2001): The prognostic relevance of angiogenesis and mast cells in squamous cell carcinoma of the oesophagus. J. Clin. Pathol. 54, 940-944.

DOI: $10.1136 /$ jep.54.12.940

FRANGOGIANNIS, N. G., M. L. ENTMAN (2006): Identification of mast cells in the cellular response to myocardial infarction. Methods Mol. Biol. 315, 91-101.

GÖRITZ, M., K. MÜLLER, D. KRASTEL, G. STAUDACHER, P. SCHMIDT, M. KÜHN, R. NICKEL, H.- A. SCHOON (2013): Canine Splenic Haemangiosarcoma: Influence of Metastases, Chemotherapy and Growth Pattern on Postsplenectomy Survival and Expression of Angiogenic Factors. J. Comp. Path. 149, 30-39.

DOI: $10.1016 /$ j.jcpa.2012.11.234

HERMAN, E., J.,A. W. STERN, R. J.FOX, MJ. J.DARK(2019): Understanding the efficiency of splenic hemangiosarcoma diagnosis using Monte Carlo simulations. Vet. Pathol. 56, 856-859.

DOI: $10.1177 / 0300985819868732$

HIROMATSU, Y., S. TODA (2003): Mast Cell and Angiogenesis. Microsc. Res. Tech. 60, 64-69.

DOI: $10.1002 /$ jemt.10244

LINDER, K. E. (2017): Tumors of the Spleen. In: Tumors in Domestic Animals. (Meuten D. J., Ed.). Wiley Blackwell. pp. 309-314.

MUKARATIRWA, S. L. CHIKAFA, R. DLIWAYO, N. MOYO (2006a): Mast cells and angiogenesis in canine melanomas: malignancy and clinicopathological factors. Vet. Dermatol. 17, 141-146.

DOI: $10.1111 / \mathrm{j} .1365-3164.2006 .00505 . \mathrm{x}$

MUKARATIRWA, S., T. CHIWOME, S. CHITANGA, E. BHEBHE (2006b): Canine transmissible venereal tumour: 
assessment of mast cell numbers as indicators of the growth phase. Vet. Res. Commun. 30, 613-621.

DOI: $10.1007 / \mathrm{s} 11259-006-3309-1$

NAKAYAMA, T., L. YAO, G. TOSATO (2004): Mast Cellderived angiopoietin-1 plays a critical role in the growth of plasma cell tumor. J. Clin. Invest. 114, 1317-1325.

DOI: $10.1172 / \mathrm{JCI} 22089$

SABATTINI, S., G. BETTINI(2009): An immunohistochemical analysis of canine haemangioma and haemangiosarcoma. J. Comp. Pathol. 140, 158-168.

DOI: $10.1016 /$ j.jcpa.2008.10.006

SCHULTHEISS, P. C. (2004): A retrospective study of visceral and nonvisceral hemangiosarcoma and hemangiomas in domestic animals. J. Vet. Diagn. Invest. 16, 522-526.

DOI: $10.1177 / 104063870401600606$

SUN, Z., J., Y. F. ZHAO, J. H. ZHAO (2007): Mast cells in hemangioma: a double-edged sword. Med. Hypotheses. $68,805-807$.

DOI: 10.1016/j.mehy.2006.09.012

TOMITA, M., Y. MATSUZAKI, T. ONITSUKI (2000): Effect of mast cells on tumor angiogenesis in lung cancer. Ann. Thorac. Surg. 69, 1686-1690.

DOI: $10.1016 / \mathrm{S} 0003-4975(00) 01160-7$

TREGGIARI, E., J. F. BORREGO, I. GRAMER, P. VALENTI, A. HARPER, R. FINOTELLO, C. TONI, P.
LAOMEDONTE, G. ROMANELLI (2020): Retrospective comparison of first-line adjuvant anthracycline vs metronomic-based chemotherapy protocols in the treatment of stage I and II canine splenic haemangiosarcoma. Vet. Comp. Oncol. 18, 43-51.

DOI: $10.1111 / \mathrm{vco} .12548$

WOLDEMESKEL, M., E. MANN, L. WHITTINGTON (2014): Tumor microvessel density-associated mast cells in canine nodal lymphoma. SAGE Open Med.

DOI: $10.1177 / 2050312114559575$

WOLDEMESKEL, M., S. RAJEEV (2010): Mast cells in canine cutaneous hemangioma, hemangiosarcoma and mammary tumors. Vet. Res. Commun. 34, 153-160.

DOI: $10.1007 / \mathrm{s} 11259-010-9341-1$

YAMAMOTO, S., K. HOSHI, A. HIRAKAWA, S. CHIMURA, M. KOBAYASHI, N. MACHIDA(2013): Epidemiological, clinical and pathological features of primary cardiac hemangiosarcoma in dogs: a review of 51 cases. J. Vet. Med. Sci. 75, 1433-1441.

DOI: 10.1292/jvms.13-0064

YAMAMOTO, T., T. UMEDA, K. NISHIOKA (2000): Immunohistological distribution of stem cell factor and KIT receptor in angiosarcoma. Acta Derm. Venereol. 80, 443-445.

DOI: $10.1080 / 000155500300012954$

Received: 29 July 2020

Accepted: 24 September 2020

\section{GUDAN KURILJ, A., K. SEVERIN, M. HOHŠTETER, B. ARTUKOVIĆ, ̌̌. GRABAREVIĆ, D. HUBER, L. MEDVEN ZAGRADIŠNIK, I. MIHOKOVIĆ BUHIN, I.-C. ŠOŠTARIĆ-ZUCKERMANN: Patološke karakteristike i broj mastocita u psećim visceralnim hemangiosarkomima. Vet. arhiv 91, 159-168, 2021. SAŽETAK}

U radu su analizirani pseći visceralni hemangiosarkomi koji su tijekom petogodišnjeg razdoblja dostavljeni u Zavod za veterinarsku patologiju Veterinarskog fakulteta Sveučilišta u Zagrebu. Utvrđena su ukupno 52 tumora u ukupno 31 psa. Analizirani su histološki obrasci rasta (kavernozni, kapilarni i solidni) te količina potporne strome tumora. Osim toga uzorci su obojeni toluidinskim modrilom radi vizualizacije mastocita te je određen njihov broj u parenhimu tumora, u stromi i na rubovima tumora. Prosječna dob zahvaćenih pasa bila je 10 godina, prevladavali su mužjaci, a tumori su najčešće nađeni kod križane pasmine, njemačkog ovčara i labradora retrivera. Najveći broj visceralnih hemangiosarkoma nađen je u slezeni (27/52). Najčešći obrazac rasta visceralnog hemangiosarkoma bio je čisti kavernozni, uz kombinaciju kavernoznog i solidnog obrasca u različitim omjerima. Mastociti su pronađeni u 44 od 52 visceralna hemangiosarkoma (84,6 \%). Manji broj mastocita nađen je u parenhimu tumora, a veći broj u stromi i na rubovima tumora. Broj mastocita u tumorima nije bio znakovito povezan s obrascem njegova rasta, ali je u svim ispitivanim tumorima utvrđena pozitivna korelacija između broja mastocita - parenhima i strome $\left(r_{s}=0,28, P<0,05\right)$, broja mastocita - strome tumora + ruba tumora $\left(\mathrm{r}_{\mathrm{s}}=0,74, \mathrm{P}<0,05\right)$ i broja mastocita - parenhima i broja mastocita - strome tumora + ruba tumora $\left(\mathrm{r}_{\mathrm{s}}=0,30, \mathrm{P}<0,05\right)$. U tumorima slezene znakovita pozitivna korelacija bila je samo između broja mastocita - stroma + ruba tumora $\left(\mathrm{r}_{\mathrm{s}}=0,68 ; \mathrm{P}<0,05\right)$. Ovi rezultati upućuju na veći broj mastocita $u$ tumorima s razvijenijim stromalnim komponentama u psećim visceralnim hemangiosarkomima. Potrebna su daljnja istraživanja uloge mastocita i čimbenika koje oslobađaju u razvoju odnosno progresiji hemangiosarkoma.

Ključne riječi: pas; visceralni hemangiosarkom; mastociti; stroma 